\title{
ANALYSIS OF THE IMPLEMENTATION OF GOOD GOVERNANCE GOVERMENT IN VILLAGE FUND MANAGEMENT BASED ON LAW NUMBER 6 OF 2014 AND REGULATION OF THE MINISTER OF HOME AFFAIRS NO. 113 IN 2014 IN WATUMEA VILLAGE ERIS SUB DISTRICT MINAHASA DISTRICT
}

\author{
Anie V. Mundung, Merry L. Sael \\ Department of Accounting, Polytechnic of Manado Country \\ DOI: $10.31364 /$ SCIRJ/v7.i10.2019.P1019710 \\ http://dx.doi.org/10.31364/SCIRJ/v7.i10.2019.P1019710
}

\begin{abstract}
The purpose of this study is to determine the village financial management, in Watumea village, Eris subdistrict, Minahasa district based on Law number 6 of 2014, and Regulation of the Minister of Home Affairs Number 113 of 2014 , thus creating a government based on Good Governance Government. In this study, researchers used a qualitative approach based on phenomena, and explored logically in accordance with scientific principles. As for this approach, to explain how effective the role of the Village Government is in implementing good village governance, in creating a suitanable economy. The results showed that the Government of Watumea Village had involved $100 \%$ of the elements of the village community, with all stages of village financial management, starting from the planning stage to the accountability stage. Financial management in Watumea Village is in accordance with the financial management mechanism in Regulation of the Minister of Home Affairs Number 113 of 2014, which adheres to 4 main principles, namely transparent, accountable, participatory, orderly and disciplined. Overall, the principles of accountability and transparency in the management of village finances in Watumea Village have been fulfilled, so that they have been based on the working principles of the Good Governance Government that have principles from the community, by the community and for the welfare of Watumea villagers.
\end{abstract}

Keywords: Transparent, Accountable, Participatory, Orderly and Discipline

I. Introduction

The village is the smallest part of the government system in Indonesia, and is a division of administrative territory under the sub-district led by the Village Head. Even though it is the smallest part, it cannot be denied that the village has a large share in state revenue. Therefore, the village received special attention from the local government to the central government. This shows how important the role of a village in supporting the stability of governance, can be seen from the amount of the budget allocated to villages which increases every year.

According to Law No. 6 of 2014, a village is a legal community unit that has the authority to regulate and manage government affairs. The interests of the local community are based on community initiatives, rights of origin, and / or traditional rights that are recognized and respected in the system of government of the Unitary Republic of Indonesia. This law regulates a village, to be able to manage and regulate its government. Provisions concerning the mechanism and procedures for managing village finances. Currently it is regulated in the provisions of Law Number 6 of 2014 concerning Villages, and Government Regulation Number 43 of 2014 concerning Regulations for the Implementation of Law Number 6 of 2014 concerning Villages. Furthermore, it is elaborated in Regulation of the Minister of Home Affairs Number 113 of 2014 concerning Village Financial Management. In the provisions of article 1 paragraph 5 it is stated that village finances are all rights, and village obligations that can be valued in money, as well as everything in the form of money and goods related to the implementation of village rights and obligations. In article 1 paragraph 6, all activities which include planning, implementing, administering, reporting, and accountability for village finances, involve village financial management. 
Regulation of the Minister of Home Affairs Number 113 of 2014 regulates that the village government has broader authority in the management of his village. Good village financial management is management that is in accordance with the guidelines set by the government, which is stated in regulation of the Minister of Home Affairs Number 113 of 2014 concerning Village Financial Management. Good village financial management is an important aspect in the success of village development and community welfare. Moreover, each year the funds allocated to each village have increased.

Recorded in the 2015 State Budget, village funds in the amount of IDR 20.7 trillion were allocated to 415 districts / cities, 7,094 sub districts, and 82,505 villages, so on average each village received village funds in the amount of IDR 749.4 million. While in 2016 the village budget has increased to IDR 47.6 trillion, and in 2017 it has again increased to IDR 60 trillion. But in reality, a significant budget increase every year is not in line with village development. This is caused by poor village financial management and deviates from the guidelines that have been provided by the central government. Unhealthy practices are also a factor in hampering village development. Regulation of the Minister of Home Affairs Number 113 of 2014 that there are five components of village financial management, namely planning, implementation, administration, reporting, and accountability. Each component of village financial management must be based on transparent, accountable, participatory principles and be carried out in an orderly and disciplined budget. Based on the above background the principles must be fulfilled so as to avoid fraud, the researcher is interested in analyzing the management of village funds based on Good Governance Government. Based on the description above, the proposing team is interested in conducting research in Watumea Village, Eris sub-district, Minahasa district to analyze village financial management based on Good Governance Government based on Law number 6 of 2014 and Regulation of the Minister of Home Affairs Number 113 of 2014. Financial management villages that are in accordance with the guidelines, will produce good governance and healthy.

\section{Research Methods}

\subsection{The method used}

In this research using a qualitative approach that is based on phenomena, and explored logically in accordance with scientific principles. This research uses a case study method developed, among others, by Yin (1986) and Dr. Boy as well as Moleong. This approach is to explain how effective the role of the village government is in implementing good village governance, in creating a suitanable economy. For this case study it matches the characteristics of the research questions, case studies relating to "how", "why", and "what". According to Yin (1996) the case study method is based on consideration of 3 conditions, namely:

1. This research is to answer the question "how", "why" or "what" contained in the formulation of the problem.

2 Researchers cannot regulate, control or influence the object of research.

3. This research is focused on contemporary events.

\subsection{Data Sources}

This research uses data collection techniques, namely:

2.2.1 Observation or field research, namely data collection techniques through direct observation of the research object. Observation technique aims to observe a social phenomenon while collecting data, as well as observing the overall symptoms or phenomena that occur. There are 2 research variables regarding this observation, which are related to conditions, and the potential of the region and the internal aspects of the target government entity.

2.2.2 Interview, aims to obtain information directly that can explain or answer the research problem concerned objectively. In this research, interviews were conducted with the Village Government and Watumea villagers. Researchers make the community as the subject of an interview because the community is the main benchmark in measuring the effectiveness of village financial management.

\subsection{Research Stages}

Several stages by the researcher are:

1. Preliminary survey of the object of research.

2. Preparation of research instruments related to the problem under study

3. Conduct interviews with parties related to the research problem

4. Collecting supporting data

5. Analyzing primary data and secondary data that has been obtained in ways - methods that have been determined.

6. Compile the final report

www.scirj.org

(C) 2019, Scientific Research Journal

http://dx.doi.org/10.31364/SCIRJ/v7.i10.2019.P1019710 


\section{Discussion}

Implementation of Law Number 6 of 2014 concerning villages was issued by Regulation of the Regulation of the Minister of Home Affairs Number 113 of 2014 concerning village financial management. For this reason, research in Watumea village, Eris Subdistrict, Minahasa Regency analyzed the Principles contained in Article 2 paragraph 1, namely the principles of transparency, accountability, participation and orderliness, and budget discipline.

\subsection{Watumea Village Financial Management Based on Regulation of the Minister of Home Affairs Number 113 of 2014}

Based on the Regulation of the Minister of Home Affairs Number 113 of 2014, village financial management includes 5 stages, namely the stages of planning, implementation, administration, reporting and accountability. In collecting data, the research team used questionnaire tools given to Ms. Vanne Sepang as the Village Head and with direct interviews with Mr. Jelly Ruru as the Village Secretary, Mr. Lucky Legoh as the Village Treasurer, other Village Apparatuses and community leaders Mr. Greiry Korompis as Village Consultative Body and Mr. Harold Sumeke as Activity and Community Management Team in Watumea Village. Following are the results of evaluations of financial management in Watumea Village.

a. Planning Phase

The Watumea Village Government has prepared a village development plan, in accordance with its duties and authorities while still paying attention to the Minahasa district development plan. Following is a description of the evaluation at the planning level by the Watumea Village Government.

\begin{tabular}{|c|c|c|c|}
\hline $\begin{array}{l}\text { Numbe } \\
\text { r. }\end{array}$ & Criteria & Yes & No \\
\hline 1 & $\begin{array}{l}\text { Has the village Secretary drafted a village regulation } \\
\text { regarding village budget and revenue, based on village } \\
\text { government work plan? }\end{array}$ & $\sqrt{ }$ & \\
\hline 2 & $\begin{array}{l}\text { Did the village secretary convey the draft village } \\
\text { regulations, the revenue budget } \\
\text { and village shopping to the village head? }\end{array}$ & $\sqrt{ }$ & \\
\hline 3 & $\begin{array}{l}\text { What is the draft village regulation, village budget and } \\
\text { Village shopping, submitted by the village head to the } \\
\text { village consultative body, for further discussion? }\end{array}$ & $\sqrt{ }$ & \\
\hline 4 & $\begin{array}{l}\text { What is the draft village regulation, village budget, and } \\
\text { village shopping agreed upon? }\end{array}$ & $\sqrt{ }$ & \\
\hline 5 & $\begin{array}{l}\text { What is the draft village regulations, village budget } \\
\text { and village shopping been submitted to the Bupati } \\
\text { for evaluation? }\end{array}$ & $\sqrt{ }$ & \\
\hline 6 & $\begin{array}{l}\text { Are the results of the evaluation followed up, and } \\
\text { improved by the Village Head to later become a Village } \\
\text { Regulation? }\end{array}$ & $\sqrt{ }$ & \\
\hline
\end{tabular}

\section{b. Implementation Stage}

In the implementation of the village budget, which has been previously determined, transactions arise both revenue and expenditure. All such receipts and expenses must be accompanied by complete and valid evidence. Watumea Village Government has fulfilled the mechanism with complete documents and transaction evidence

\begin{tabular}{|l|l|l|l|}
\hline $\begin{array}{l}\text { Numb } \\
\text { er. }\end{array}$ & Criteria & Yes & No \\
\hline
\end{tabular}




\begin{tabular}{|c|c|c|}
\hline 1 & $\begin{array}{l}\text { Does the village government, are prohibited from making } \\
\text { levies as village revenue, other than those stipulated in } \\
\text { the village regulations? }\end{array}$ & $\sqrt{ }$ \\
\hline 2 & $\begin{array}{l}\text { Can the Treasurer save a certain amount of money in the } \\
\text { Village Treasury, in order to meet the operational needs } \\
\text { of the village government? }\end{array}$ & \\
\hline 3 & $\begin{array}{l}\text { Can village expenditures incur a burden on the Village } \\
\text { Budget, and the Village Expenditure cannot be carried } \\
\text { out before the village regulation draft, regarding Village } \\
\text { Budget Revenue and Expenditure, is determined to be a } \\
\text { village regulation? }\end{array}$ & $\sqrt{ }$ \\
\hline 4 & $\begin{array}{l}\text { Is village expenditure not included for binding personnel } \\
\text { expenditure, and office operations as stipulated in the } \\
\text { regulations of the village head? }\end{array}$ & $\sqrt{ }$ \\
\hline 5 & $\begin{array}{l}\text { Does the use of unexpected costs first need to be made } \\
\text { Details of the Budget Budget that has been approved by } \\
\text { the Village Head? }\end{array}$ & $\sqrt{ }$ \\
\hline 6 & $\begin{array}{l}\text { Does the Activity Implementer submit funding to carry } \\
\text { out activities must be accompanied by documents, } \\
\text { including a Cost Budget Plan.? }\end{array}$ & $\sqrt{ }$ \\
\hline 7 & $\begin{array}{l}\text { Is the Budget Plan verified by the Village Secretary and } \\
\text { approved by the Village Head? }\end{array}$ & $\sqrt{ }$ \\
\hline 8 & $\begin{array}{l}\text { Is the Activity Implementer responsible for the actions of } \\
\text { expenditure, which causes the burden of the activity's } \\
\text { expenditure budget by using the activity cash ledger as } \\
\text { the responsibility for implementing the activities in the } \\
\text { village? }\end{array}$ & $\sqrt{ }$ \\
\hline 9 & $\begin{array}{l}\text { Is the village treasurer obliged to collect income tax, and } \\
\text { other taxes, must deposit all receipt of deductions and } \\
\text { taxes collected to the state treasury account, in } \\
\text { accordance with statutory provisions? }\end{array}$ & $\sqrt{ }$ \\
\hline 10 & $\begin{array}{l}\text { Is there good coordination between the village head, } \\
\text { village secretary, village treasurer? }\end{array}$ & $\sqrt{ }$ \\
\hline
\end{tabular}

\section{c. Administration Stage}

Administration is a recording activity that is specifically carried out by the Village Treasurer. The administration media in the form of general cash books, tax books, bank books, and monthly accountability reports are made directly by the Village Treasurer. The following are the results of the evaluation of the administration activities carried out by the Treasurer of Watumea Village.

\begin{tabular}{|c|l|c|c|}
\hline $\begin{array}{c}\text { Numb } \\
\text { er. }\end{array}$ & \multicolumn{1}{|c|}{ Criteria } & Yes & No \\
\hline 1 & $\begin{array}{l}\text { Did the Treasurer of Watumea Village make a public } \\
\text { cash book? }\end{array}$ & $\sqrt{ }$ & \\
\hline 2 & $\begin{array}{l}\text { Did the treasurer of the village of Watumea make a cash } \\
\text { book of tax assistants? }\end{array}$ & $\sqrt{ }$ & \\
\hline
\end{tabular}




\begin{tabular}{|c|l|l|l|}
\hline 3 & $\begin{array}{l}\text { Did the Treasurer of the Watumea Village make a bank } \\
\text { book? }\end{array}$ & $\sqrt{ }$ & \\
\hline
\end{tabular}

www.scirj.org

(C) 2019, Scientific Research Journal

http://dx.doi.org/10.31364/SCIRJ/v7.i10.2019.P1019710 


\section{d. Reporting Phase}

The Regulation of the Minister of Home Affairs Number 113 of 2014 explains that in carrying out its duties, authorities and rights, the Village Head is obliged to report on the use of village funds.

\begin{tabular}{|c|l|c|c|}
\hline $\begin{array}{c}\text { Numbe } \\
\text { r. }\end{array}$ & \multicolumn{1}{|c|}{ Criteria } & Yes & No \\
\hline 1 & $\begin{array}{l}\text { Does the Village Head submit the Realization Budget } \\
\text { Report, and Village Shopping to the Regent? }\end{array}$ & $\sqrt{ }$ & \\
\hline 2 & $\begin{array}{l}\text { Does the Village Head submit the First Semester } \\
\text { Report in the form of Realization Budget Realization } \\
\text { Reports and Village Shopping? }\end{array}$ & $\sqrt{ }$ & \\
\hline 3 & $\begin{array}{l}\text { Does the Village Head submit the End of Year } \\
\text { Semester Report? }\end{array}$ & $\begin{array}{l}\text { Implementation of the Village Government at the end } \\
\text { of each year, the budget to the Regent? }\end{array}$ & $\sqrt{ }$ \\
\hline 5 & $\begin{array}{l}\text { Does the Village Head submit the Village Government } \\
\text { Implementation Report, at the end of each term? }\end{array}$ & $\begin{array}{l} \\
\text { Does the Village Head submit the Repont on the } \\
\text { village administration to the Village Consultative Body } \\
\text { at the end of the year? }\end{array}$ & $\sqrt{ }$ \\
\hline
\end{tabular}

e. The accountability stage

The items of responsibility in the Regulation of the Minister of Home Affairs Number 113 of 2014 are as follows.

\begin{tabular}{|c|l|c|c|}
\hline $\begin{array}{c}\text { Numbe } \\
\text { r. }\end{array}$ & \multicolumn{1}{|c|}{ Criteria } & Yes & No \\
\hline 1 & $\begin{array}{l}\text { Does the Village Head submit the accountability report } \\
\text { on the implementation of the Revenue Budget, and } \\
\text { Village Shopping to the Regent through the sub district } \\
\text { head at the end of each year the budget? }\end{array}$ & $\sqrt{ }$ & $\sqrt{ }$ \\
\hline 2 & $\begin{array}{l}\text { Is the accountability report on the realization of the } \\
\text { implementation of the Revenue Budget, } \\
\text { and Village expenditure consists of income, } \\
\text { expenditure and financing? }\end{array}$ & & \\
\hline
\end{tabular}




\begin{tabular}{|c|l|l|l|}
\hline 3 & $\begin{array}{l}\text { Is the accountability report, the realization of the } \\
\text { implementation of the Revenue Budget and Village } \\
\text { Expenditure is delivered no later than 1 month after } \\
\text { the end of the fiscal year regarding? }\end{array}$ & $\sqrt{ }$ \\
\hline
\end{tabular}

\subsection{Evaluation of Financial Management of Watumea Village Based on the Good Governance Government Principle, the Regulation of the Minister of Home Affairs Number 113 of 2014}

The results of interviews between the research team and resource persons, in this case the Head of Watumea Village, the Village Secretary, the Village Treasurer, community leaders in Watumea Village and other village officials, showed that the running of the government in Watumea Village had fulfilled aspects of Good Governance Government, namely transparency, accountability, participatory and orderly, and budgetary discipline in empowering every element of society that exists.

\begin{tabular}{|c|c|c|c|c|c|}
\hline \multirow{2}{*}{ Object } & \multicolumn{2}{|c|}{$\begin{array}{c}\text { Regulation } \\
\text { No. 113 of 2014 }\end{array}$} & \multicolumn{3}{c|}{ Good Governance } \\
\cline { 2 - 6 } & Disagree & Agree & $\begin{array}{c}\text { Transparen } \\
\text { t }\end{array}$ & Accountability & Society participation \\
\hline Village government : : & & & & & \\
\hline $\begin{array}{c}\text {-Old Law (Village } \\
\text { Head) }\end{array}$ & & $\sqrt{ }$ & $\sqrt{ }$ & $\sqrt{ }$ & \\
\hline -Village secretary & & $\sqrt{ }$ & $\sqrt{ }$ & $\sqrt{ }$ & \\
\hline -Treasurer & & $\sqrt{ }$ & $\sqrt{ }$ & $\sqrt{ }$ & \\
\hline $\begin{array}{c}\text {-Other village } \\
\text { officials }\end{array}$ & & $\sqrt{ }$ & $\sqrt{ }$ & $\sqrt{ }$ & \\
\hline Financial Management & & & & $\sqrt{ }$ & \\
\hline -Budget plan & & $\sqrt{ }$ & $\sqrt{ }$ & $\sqrt{ }$ \\
\hline -Implementation & & $\sqrt{ }$ & $\sqrt{ }$ & $\sqrt{ }$ \\
\hline -Reporting & & $\sqrt{ }$ & $\sqrt{ }$ & $\sqrt{ }$ & \\
\hline -Accountability & & $\sqrt{ }$ & $\sqrt{ }$ & $\sqrt{ }$ \\
\hline
\end{tabular}

The results obtained through the matrix checklist that the process of financial management, especially the government has been based on the principles of good governance government. Village financial management starts from the stages of planning, implementation, reporting, and accountability in accordance with existing mechanisms. The Regulation of the Minister of Home Affairs Number 113 of 2014 and has involved villagers who in this case are represented by the Village Consultative Body and based on:

1) The principle of transparency, namely the village government in managing, the Village Budget and Revenue have carried out in accordance with the legal methods, or regulations that apply to avoid conflicts in the community, so as to obtain community legitimacy. And to obtain accountability reports, may contact the old law, or the village head. In the principle of transparency the village government announces through village meetings, such as the monthly interfaith religious cooperation body, party events, and even in the event of death, the government takes the opportunity to socialize also through billboards, banners and bulletin boards.

2) Accountable Principle, which starts from the planning process, implementation, until the accountability has been carried out in accordance with the prevailing system, which starts from the deliberation of guard, village musyaarawah to the responsibility of the above levels of government, in accordance with statutory regulations.

3) Participatory Principle, which has included direct and indirect community involvement. Through representative institutions to convey their aspirations through the Village Consultative Body. Seen from the people of Watumea village themselves, who feel they have even grown self-sufficiency in starting construction through community service at the beginning, to facilitate work in accordance with the established budget.

4) Orderly principles, and budgetary discipline, namely the village government has consistently carried out in accordance with WwW.scirj.org

(C) 2019, Scientific Research Journal

http://dx.doi.org/10.31364/SCIRJ/v7.i10.2019.P1019710 
the village budget, and records have been made of use in accordance with the principles of village financial accounting. With the aim to avoid irregularities, and improve the professionalism of its management

Based also on the results of interviews conducted with the village government, in this case the Head of Watumea Village, Ms. Vanne Sepang said, although there were problems that arose, namely the number of NGOs in the village, which of course also had an impact on spending disbursed to each NGO. However, this can be overcome. In the end, the government and development in Watumea village is from the community, by the community, and for the welfare of the village community.

\section{Conclusion}

Research activities by the Manado State Polytechnic Team of Accounting Department in Watumea Village, Eris Subdistrict, Minahasa District on Evaluation of Village Financial Management Based on Good Governance Government, can be concluded as follows:

1. Watumea Village Government has involved $100 \%$ of the elements of the village community with all stages of village financial management, starting from the planning stage to the accountability stage.

2. Financial management in Watumea Village is in accordance with the financial management mechanism in The Regulation of the Minister of Home Affairs Number 113 of 2014 which adheres to 4 main principles namely transparent, accountable, participatory, orderly and disciplined.

3. Overall, the principles of accountability and transparency in the management of village finances in Watumea Village have been fulfilled, so that they have been based on the working principles of Good Governance Government which have principles from the community, by the community and for the welfare of Watumea villagers.

\section{References}

Amelia, Ira, dkk. 2012. The Effect of Good Governance, Internal Control, and Organizational Culture on Government Performance.

Embodiments of Transparency and Public Accountability, Through Public Sector Accounting: A Means of Good Governance. Journal of Government Accounting Vol. 2, No. 1

IFAC, 2012. Public Sektor Financial Management Transparency And Accountability: The Use Of International Public Sector Accounting Standrards. IFAC Pilicy Position.

Law No. 6 of 2014 concerning Villages.

Law Number 23 of 2014

Mardiasmo, 2006. Manifestation of Transparency and Public Accountability through Public Sector Accounting: A Means of Good Governance. Journal of Government Accounting Vol. 2, No. 1

Sabarguna, Boy S., Haji. "Data Analysis in Qualitative Research", Jakarta: University of Indonesia Publisher (UI-Press), 2004. The Regulation of the Minister of Home Affairs Number 113 of 2014.

UNDP [ United Nations Development Programme ]. 2004. Annual Report 2003 of the Adminstrator. UNDP. New York YIN, Robert K. 2004“Case Study Design and Method”. Jakarta : PT. Raja Grafindo Persada. 